\title{
A NEW LARGE-FLOWERED CYRTOCHILUM (ORCHIDACEAE: ONCIDIINAE) FROM ECUADOR, NAMED IN HONOR OF TWO ORCHID RESEARCH LEGENDS
}

\author{
STIG DALSTRÖM \\ 2304 Ringling Boulevard, unit 119, Sarasota FL 34237, U.S.A. \\ stigdalstrom@gmail.com
}

\begin{abstract}
A new and attractive but little-known Cyrtochilum (Orchidaceae: Oncidiinae), which was previously misidentified as Cyrtochilum aemulum, is named in honor of the 95th birthdays of Carlyle August and Jane Hortense Pfeiffenberger Luer of Sarasota, Florida, the most prolific orchid research couple the world has ever known. The background of how the author first became acquainted with the legendary researchers is featured here together with color photographs of them taken by the author on various occasions during their long career. The new Cyrtochilum is described, illustrated and compared with the rather similarly colored C. aemulum. The new species is distinguished from it by the combination of geniculated and shortly spathulate bases of the petals and a glabrous, more erect and more complex lip callus versus shortly unguiculate bases of the petals and a finely micro-pubescent and a horizontally flatter and more simple lip-callus of C. aemulum.
\end{abstract}

KeY wORDS: Cyrtochilum aemulum, Ecuador, Oncidiinae

Introduction. Late on November 6, 1981, I arrived at the Trailways bus station in Sarasota Florida. It had been a long and exhausting journey with a flight from Stockholm, Sweden, to Miami where the night was spent at a "shady" hotel in an even more "shady" neighborhood near the bus station. After a short night's sleep, an early departure and a seven hour bus trip it was with some nervous anticipation I looked forward to finally meet the famous Dr. Carlyle "Carl" Luer and his wife Jane (Figs. 1-4), and to visit the recently opened Marie Selby Botanical Gardens in Sarasota. I really had no reason to be nervous as it turned out because Carl and Jane welcomed me as part of their family. There was also love at first sight when Carl introduced me to Selby Gardens, as it is generally referred to. The research staff under its charismatic director Calaway "Cal" $\mathrm{H}$. Dodson (Fig. 5) also welcomed me as a member of the team. It did not take long for me to realize that this was going to be my future!

The reason I had been invited to visit Selby Gardens was because they were always looking for botanical illustrators, particularly ones that had field experience and an interest in orchids. I had already visited Thailand and Ecuador a couple of times, and I certainly had a great interest in orchids so I fit those requirements. The illustration part was a slightly different story though. Although I had always enjoyed drawing, my scientific and technical skills were yet to be developed. But when I learned about a botanical garden in Florida that specialized in epiphyte research and particularly orchids, I decided to step out of my comfort zone and give it a try. A letter was sent to director Dodson where I introduced myself as a botanical illustrator, specializing in orchids from Ecuador (knowing that Dodson had a great personal and professional interest in the orchid flora of that country). Dodson's reply was short and to the point: "Send some samples!"

The dice were cast and I had to produce something to prove I was what I said I was. After having studied some of my hastily composed "botanical illustrations", Dodson asked Carl to invite me to come by for further discussions the next time I headed for Ecuador. And finally there I was.

In the beginning I produced illustrations mainly for Dodson. As my skill improved over the years Carl began to trust my ability to meet his exquisite requirements and one day he asked me if I would be interested in making watercolor illustrations for a project he had in mind. This was the monumental Thesaurus Dracularum, a monographic treatment of the genus Dracula Luer, with 


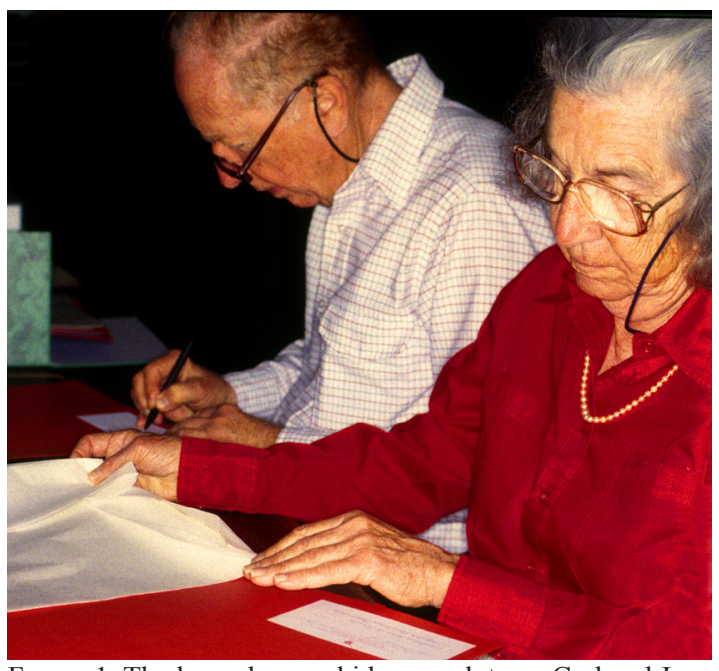

FigURE 1. The legendary orchid research team Carl and Jane Luer at work. Photo by S. Dalström.

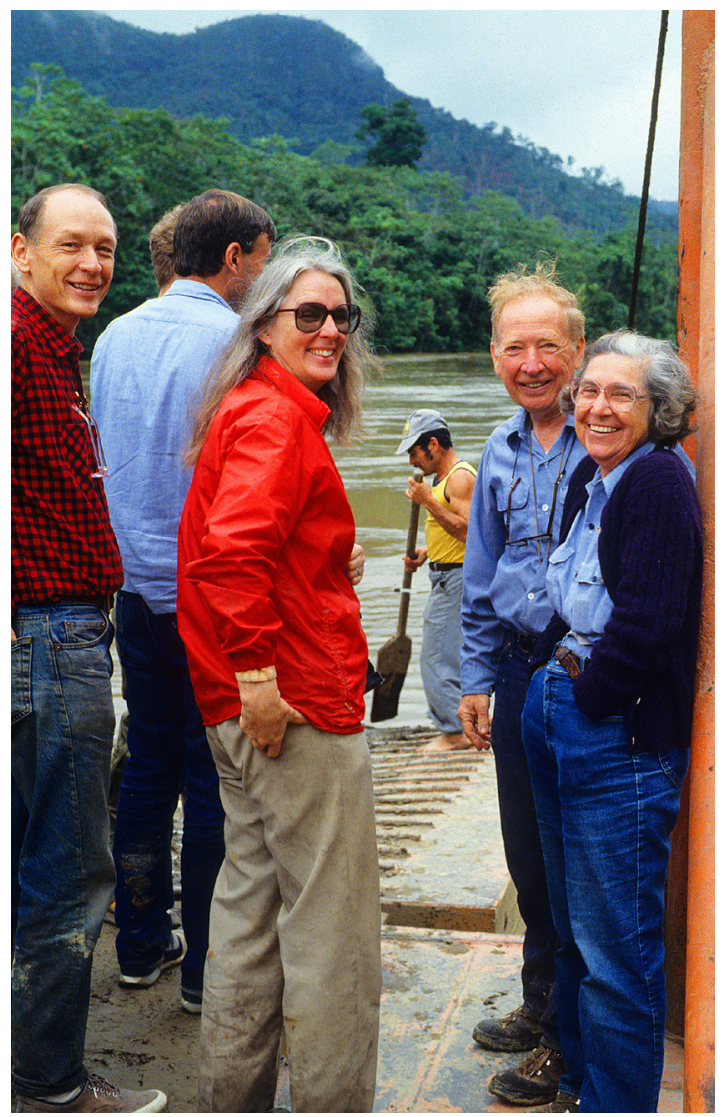

Figure 3. Phil and Ann Jesup ready to cross Rio Zamora on a barge together with Carl and Jane Luer. Photo by S. Dalström.

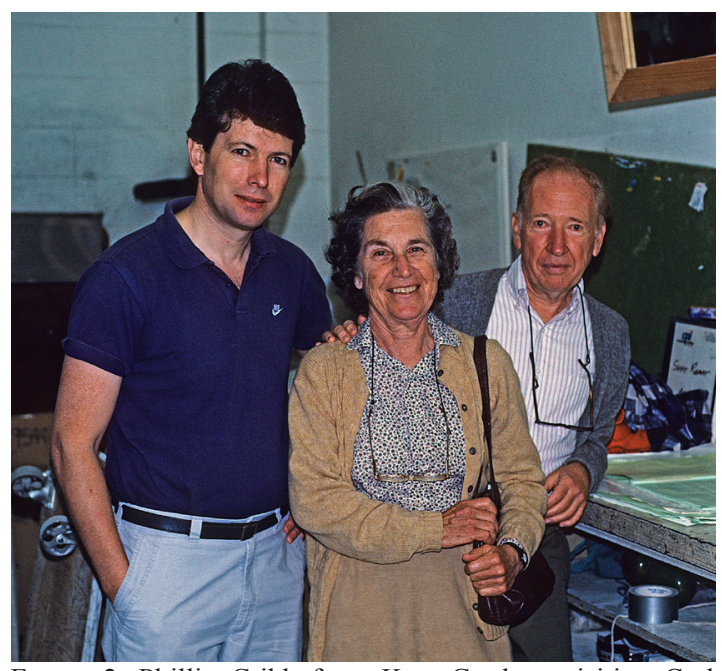

Figure 2. Phillip Cribb from Kew Gardens visiting Carl and Jane Luer in Sarasota, inspecting color proofs of Thesaurus Dracularum. Photo by S. Dalström.

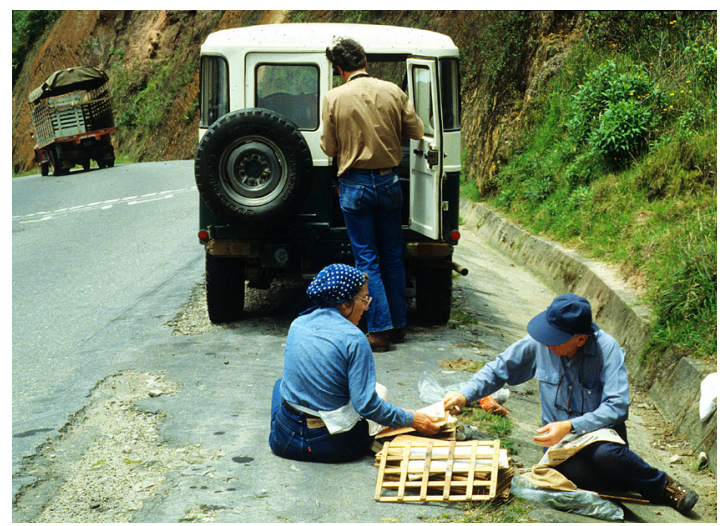

FIgure 4. Carl and Jane Luer, together with Walter C. Teague, pressing freshly collected specimens on a highway road in Colombia. Photo by S. Dalström.

life-sized illustrations of all known species, published by Missouri Botanical Gardens. I had only made a single watercolor illustration before that so it was with some trepidation I accepted. It was tricky in many ways to work with these peculiar flowers due to all the hairs, warts and diminutive details. In addition, the plants were mainly growing at higher altitudes in the Andean cloud forests and could not be cultivated in Florida, so I had to study them in the field and work from photographs. Some species did not even exist in any living collection known to us so Carl and Jane and I together with many others had to try and track them down in their unknown jungle hideaways. During this process many new 


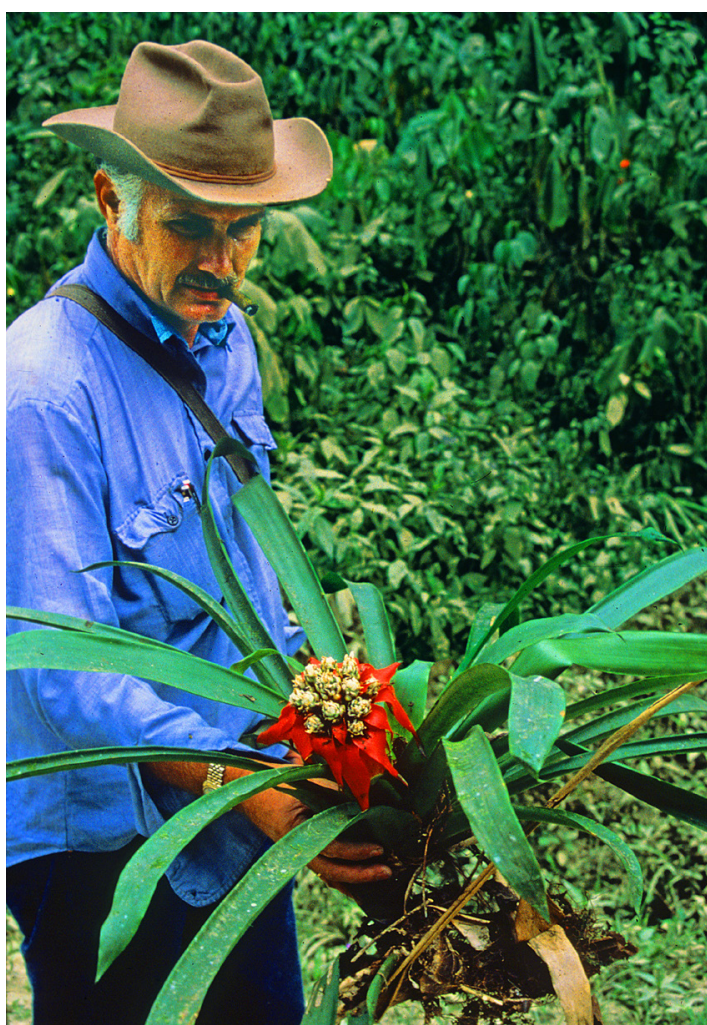

Figure 5. The charismatic Calaway H. Dodson in the field in Ecuador. Photo by A. Embree.

species were subsequently discovered and described. Thesaurus Dracularum was followed by $A$ Treasure of Masdevallia, and several thousand ink illustrations over the years.

Carl's and Jane's scientific work is entirely restricted to the taxonomy of plants in the Pleurothallidinae. My personal research focus, on the other hand, has from the beginning been focused on plants in the Oncidiinae and I intended to keep it that way. But during a couple of wonderful field trips to Colombia and Ecuador together with Carl and Jane, I was inevitably "sucked" into working with pleurothallids as well, particularly genera Dracula and Masdevallia Ruiz \& Pav. So during our expeditions we collected plants of both subtribes and were successful in finding many new species. One of these was a Cyrtochilum Kunth (Figs. 6-9) that I originally identified as C. aemulum (Rchb.f. \& Warsz.) Kraenzl. It was featured as such in my treatment of Cyrtochilum for Flora of Ecuador (Dodson \& Luer, 2010). Recent re-examinations of the type of $C$. aemulum show that this identification was incorrect and that the Ecuadorean plant represents a new species, which is described here. The reexamination of the type of $C$. aemulum also revealed that it is possibly an older name for $C$. grandiflorum (Rchb.f.) Kraenzl., but this will be further investigated in the future. Although Carl and Jane Luer will always be remembered as orchid research legends in the field of Pleurothallidinae, it is less known but no less important that they have also contributed to the knowledge of other orchid genera through their various collections. It is therefore with great pleasure I name this attractive Cyrtochilum in their honor.

Unfortunately, very little is known about this species and only an alcohol preserved flower exists as a type specimen, aside from the existing color photographs. Using a single flower as a type specimen is understandably quite unsatisfactory, but not unheard of. The holotypes of Cyrtochilum davisii (Rchb.f.) Dalström, C. detortum (Rchb.f.) Kraenzl., and C. ionodon (Rchb.f.) Dalström are all represented by a single flower. When no other material is known of the species described here and doing field collecting in Ecuador is basically out of the question these days, particularly in high risk areas near the Colombian border where this plant was found, there is little else to do but to accept reality, "bite the bullet" and proceed with the documentation. This species needs a name.

\section{TAXONOMIC TREATMENT}

\section{Cyrtochilum luerorum Dalström, sp. nov.}

TYPE: Ecuador. Carchi: Above Maldonado along the road to Tulcan, terrestrial in dense shrubs close to the road, alt. ca. 2500 m. Mar. 1992, S. Dalström et al. 1563 (holotype: SEL; flower in alcohol). Fig. 6.

Diagnosis: Cyrtochilum luerorum is distinguished from the similar C. aemulum by the combination of the geniculated and rather spathulate bases of the petals, which angles the petals upwards and a glabrous, more erect and more complex lip callus versus shortly unguiculate bases of the petals, and a finely micropubescent and horizontally flatter and more simple lipcallus of C. aemulum.

Terrestrial or epiphytic herb. Plant not properly diagnosed. Pseudobulbs not properly diagnosed. 


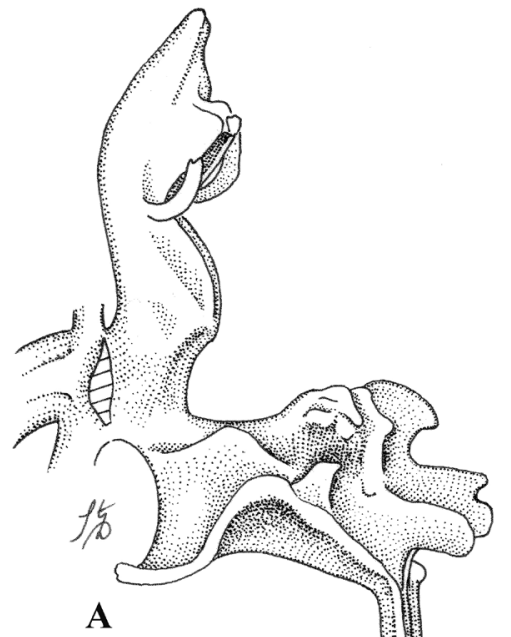

$5 \mathrm{~mm}$

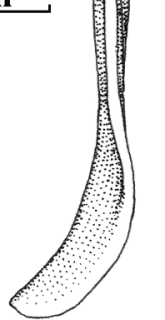

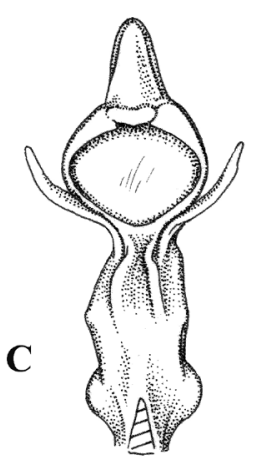

D

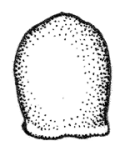

(W)

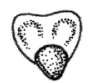

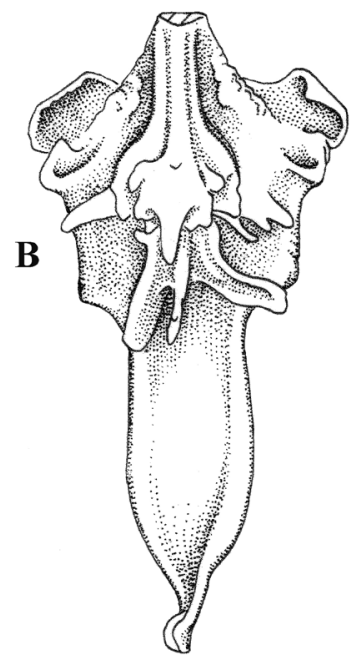

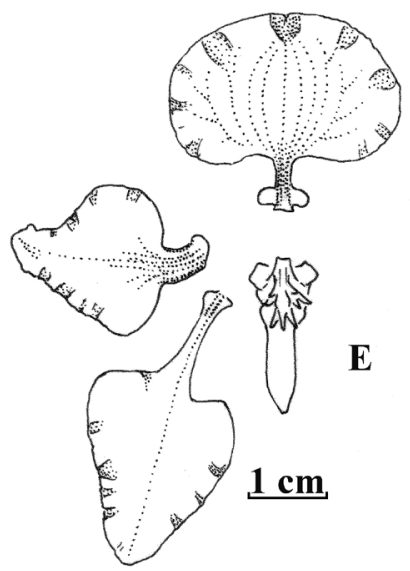

FiguRE 6. Cyrtochilum luerorum Dalström. A. Column and lip, lateral view. B. Lip, dorsal view. C. Column, ventral view.

D. Anther cap and pollinarium, frontal views. E. Flower dissected. Drawn from the holotype by S. Dalström.

Inflorescence axillary from the base of the uppermost sheath, long and wiry to several meters long panicle, with widely spaced, few-flowered branches. Bracts conspicuous, involute-cucullate, ca. 10-12 mm long. Pedicel with ovary ca. $15 \mathrm{~mm}$ long. Flowers more or less stellate to rather floppy; dorsal sepal brown with a white edge and apex, basally auriculate, unguiculate, then cordate to truncate, broadly reniform, undulate, ca. $25 \times 30 \mathrm{~mm}$; lateral sepals similar in color, basally rudimentary auriculate, elongate spathulate, then hastate to cuneate and broadly ovate, obtuse, undulate, $c a .38 \times$ $21 \mathrm{~mm}$; petals basally yellow, then spotted with purple turning into solid brown with a larger white apical area, basally geniculate, which angles the lamina upwards, shortly spathulate, then distinctly hastate and broadly ovate, obliquely obtuse to acute, undulate and more or less lacerate, ca. $25 \times 20 \mathrm{~mm}$; lip basally yellowish brown, then reddish brown with a white apex, rigidly attached to the base of the column, unguiculate, hastate to cordate, trilobed with short, truncate, slightly concave side-lobes, with a fleshy ridge leading onto the elongate, ligulate, apically recurved and indistinctly canaliculated, acute front-lobe, ca. $20 \times 10 \mathrm{~mm}$; callus yellow near the base, then white and gradually turning purple to orange with a white apex, of a fleshy, complex, rather erect, tuberous, spreading multi-denticulate structure extending from the base up to almost half the length of the lamina ending with a central and two lateral spreading vertically flattened keels; column basally yellow, apically purple, clavate, erect and away from the lip, indistinctly sigmoid, basally terete and apically elongate obtuse, then ventrally canaliculate with an erect, falcate, 


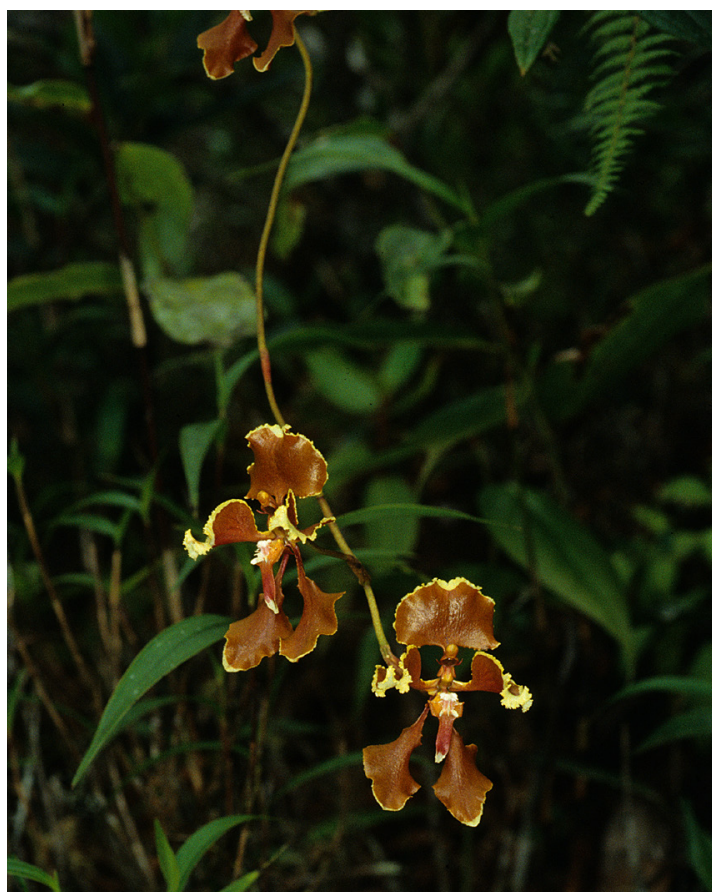

FigURE 7. The plant that became the holotype of Cyrtochilum luerorum in situ, Carchi, Ecuador. Photo by S. Dalström.

digitate wing on each side of the stigmatic surface, $c a$. $12 \mathrm{~mm}$ long; anther cap pale brownish, campanulate, dorsally lobulate, broadly rostrate; pollinarium of two obovoid, cleft pollinia on a rounded obtriangulate, $c a$. $2 \mathrm{~mm}$ long stipe on a pulvinate viscidium.

Paratype: Ecuador. Without known locality. Plant cultivated by Angel Andreetta and photographed by him (SEL and Dalström archives: color transparencies).

DistriBution: Cyrtochilum luerorum is a poorly known species that is only documented from a single locality in northwestern Ecuador.

Eponymy: Named in honor of Carlyle A. and Jane H. P. Luer of Sarasota, Florida, who have contributed more to the understanding and classification of Pleurothallid orchids than any other individuals ever.

AcknOwLEdgments. I sincerely thank Carl and Jane Luer for their never failing support over many years of collaboration and friendship. I thank Calaway Dodson for believing in my potential illustration skills and supporting the beginning of my scientific career. I also thank Wesley E. Higgins and other anonymous viewers for commenting on and improving the manuscript.

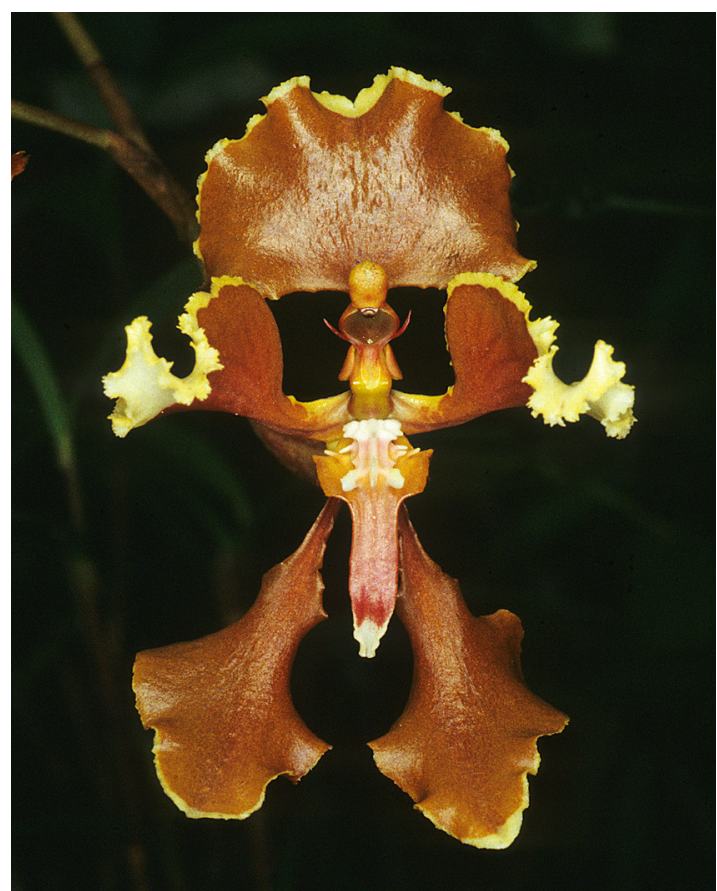

FIGURE 8. Cyrtochilum luerorum, close-up of a flower of the plant that became the holotype. Photo by S. Dalström.

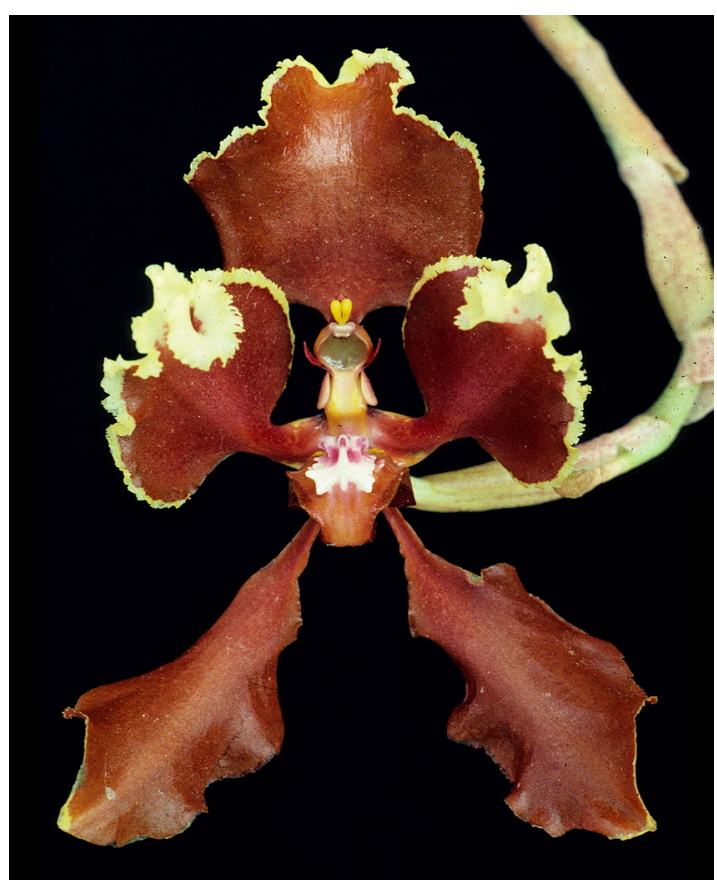

Figure 9. Cyrtochilum luerorum, the only other known record of this species, from an unknown locality, cultivated in Cuenca by the Salesian Missionary Father Ángel Andreetta and photographed by him.

LANKESTERIANA 17(2). 2017. (C) Universidad de Costa Rica, 2017. 


\section{LITERATURE CITED}

Dodson, C. H. \& C. A. Luer (2010). Orchidaceae, Genera Cyrtochiloides-Epibator. In: G. Harling \& C. Persson (eds.). Flora of Ecuador. Riksmuseum, Stockholm, Department of Plant and Environmental Sciences, Göteborg University, and the Section for Botany. 